\title{
Entrepreneurial learning from observing role models
}

\author{
Ricardo Zozimo*, Sarah Jack, Eleanor Hamilton \\ Department of Entrepreneurship, Strategy and Innovation \\ Lancaster University Management School \\ Lancaster University, $U K$
}

*Corresponding author. Email: r.zozimo@lancaster.ac.uk 


\title{
Entrepreneurial learning from observing role models
}

\begin{abstract}
This study examines entrepreneurial learning through the observation of role models. Adopting an interpretive and inductive approach, and using biographical interviews and life course techniques, the article examines how sixteen entrepreneurs articulate their entrepreneurial learning from role models. The overarching research question 'How do entrepreneurs learn from observing role models?' enables illustrating who the role models are (parents, teachers, colleagues, other entrepreneurs), the relevant social contexts (home, education, workplace) and what is learned in relation to entrepreneurial learning tasks (learning about oneself, managing relationships, the business and small business management). The study contributes to developing the social perspectives of entrepreneurial learning by demonstrating the significance of learning from role models in different social contexts and at distinct entrepreneurial stages pre- and post-start-up.
\end{abstract}

Keywords: entrepreneurial learning; role models; observation; life course; social context

\section{Introduction}

Entrepreneurial learning is recognised as critical to advancing knowledge on entrepreneurship (Wang and Chugh 2014). This has led to calls for more understanding on how individuals learn from others (Cope 2005; Hamilton 2011; Konopaski, Jack, and Hamilton 2015; Pittaway and Thorpe 2012) and particularly how entrepreneurs learn through observing individuals with whom they interact in social contexts and who are often referred to as role models (Bosma et al. 2012; Hoffmann, Junge, and Malchow-Møller 2015).

Previous studies show that observing role models such as parents (Hoffmann et al. 2015; Mungai and Velamuri 2011), guest speakers (Fiet 2001), school or university peers (Kacperczyk 2012), workplace colleagues (Nanda and Sorensen 2010) and other 
entrepreneurs (Bosma et al. 2012) generates higher levels of self-efficacy, increases entrepreneurial intentions and leads to acquiring business-related practices (Bosma et al. 2012). However, current theoretical perspectives tend to neglect the social context and how this affects the ways in which role model observation occurs (Taylor and Thorpe 2004). Given that such observation is clearly influenced by the social situations that entrepreneurs encounter (Rae and Carswell 2000; Sardana and Scott-Kemmis 2010), this lack of understanding on the relationship between observing role models, the social context and how this affects entrepreneurial learning is surprising.

In this study, we offer a deeper understanding of how entrepreneurial learning takes place through observing role models. We address the overarching research question: 'How do entrepreneurs learn from observing role models?' and two interrelated sub-questions. The first concerns the social context: 'Where and how are role models observed?' and the second examines the content of entrepreneurial learning: 'What is learned from observing role models?' The theoretical foundations of this study are informed by the work of Bandura (1977) and Cope (2005). While insights from social learning theory (Bandura 1977) are essential to understanding the process of how role models are observed, the seminal work of Cope (2005) guides our understanding in relation to what entrepreneurs learn. Drawing on these two theoretical frameworks enables us to better frame the role model process and content within the entrepreneurship context.

Using an interpretive and inductive approach (Gephart 1999; Jaskiewicz, Combs, and Rau 2015), we draw on one-to-one biographical interviews (Belli and Callegaro 2009) with sixteen different entrepreneurs. The iterative analysis of life course techniques and procedures (Giele and Elder 1998a) enable us to show how participants articulate interactions with role models in terms of learning along their entrepreneurial journey (Kempster 2009; Rae and Carswell 2001). 
Our contribution advances understanding on how entrepreneurial learning takes place through role models on a theoretical level. We do this by illustrating who the role models are (parents, teachers, colleagues, other entrepreneurs), the relevance of specific social contexts (home, education, workplace) and what is learned in relation to entrepreneurial learning tasks (learning about oneself, managing relationships, the business and small business management). In doing so, this study identifies distinct learning patterns from role models at two stages of the entrepreneurial journey, namely, pre- and post-start-up.

\section{Theoretical background}

Current understanding of how entrepreneurs learn has developed substantially in the last decade (Wang and Chugh 2014). Although most theorising still focuses on the role of individual experiences, social understanding of entrepreneurial learning is emerging. Advocates of this latter perspective argue that studying the social and historical context in which entrepreneurial learning occurs is vital as this provides a more complete understanding of the phenomenon (Hamilton 2013; Pittaway and Thorpe 2012; Taylor and Thorpe 2004).

Notwithstanding the calls to develop further understanding on how entrepreneurs learn from others (Cope 2011), entrepreneurial learning literature has been slow in developing frameworks that enable fully comprehending the wealth and complexity of social learning in entrepreneurship (Wang and Chugh 2014). Despite the absence of a comprehensive framework, substantial knowledge has been generated in specific areas that deal with the overall issue of how entrepreneurs learn from others. For example, recent studies demonstrate how family members (Hamilton 2011; Konopaski et al. 2015) or work colleagues (Nanda and Sorensen 2010) learn from each other in the context of entrepreneurship.

More broadly, literature on entrepreneurial learning has developed substantial insights into how entrepreneurs learn from observing others (Holcomb et al. 2009) and specifically from role models. Role models are thought to be individuals who demonstrate noteworthy 
behaviours or engage in cyclical social interactions with entrepreneurs (Hoffmann et al. 2015). In this thus logical to assume that entrepreneurs learn from observing those who trigger individual reflections on entrepreneurial goals and objectives (Radu and Loue 2008). Role models are described as accessible, successful individuals (Bosma et al. 2012) who generate higher levels of entrepreneurial intentions and motivations in others for an entrepreneurial career (Van Auken, Fry, and Stephens 2006). Indeed, the presence of role models is often associated with enhanced regional and national entrepreneurial eco-systems (Lafuente, Vaillant, and Rialp 2007).

Conceptually, prior studies suggest that learning from observing role models is governed by vicarious or observational processes (Holcomb et al. 2009; Rae and Carswell 2001; Sardana and Scott-Kemmis 2010). While other disciplines marginally distinguish between these two forms of learning, scholars in the entrepreneurial learning domain argue that they represent similar learning processes and therefore use these terms interchangeably. Drawing on the influential work of Bandura (1977) and social learning theory, we refer to observational learning as the process through which entrepreneurs learn from observing role models (Gibson 2004).

\section{Outcomes of role model observation in entrepreneurship}

When exploring the impact of role models on entrepreneurship, prior studies accentuate the relevance of specific groups of role models in the formation of entrepreneurial intentions and behaviour. For example, a substantial claim in literature is that entrepreneurial parents act as role models for their children (Hoffmann et al. 2015; Scherer et al. 1989). Studies suggest that observing and interacting with entrepreneurial parents leads to increasing entrepreneurial intentions (Scherer et al. 1989). Others argue that by interacting with parental role models, children become sensitised to the world of entrepreneurship and acquire critical skills and abilities (Hamilton 2011). Research also posits that children of financially successful 
entrepreneurs are more likely to observe their parents and consequently choose similar careers (Dunn and Holtz-Eakin 2000). Collectively, these studies underline the importance of parental role models for entrepreneurship, describing in-depth the outcomes of observing parents in terms of propensity for entrepreneurship, influence on motivations to become an entrepreneur and the outcomes fostered by these observations.

Studies in university settings also show that entrepreneurial guest speakers often function as role models for students (Bosma et al. 2012; Erikson 2003). By sharing details of their particular entrepreneurial trajectories, guest speakers provide descriptions of behaviours and practices associated with entrepreneurship (Fiet 2001). This sharing process allows students to create an image of what entrepreneurs do and the difficulties and challenges associated with their endeavours (Shepherd 2004). Exposure to multiple guest speakers is thought to increase students' self-efficacy (Boyd and Vozikis 1994), motivational levels towards pursuing an entrepreneurial career (Radu and Loue 2008; Van Auken et al. 2006) and the overall impact on decision-making processes associated with entrepreneurship (Segal, Schoenfeld, and Borgia 2007). Empirical studies describe the process of observing guest speakers as abstract rather than direct observational learning (Radu and Loue 2008). In abstract observational learning, students rely on the descriptions that guest speakers offer to construct their own image of the challenges associated with entrepreneurial endeavours. Conceptual and empirical studies on guest speakers would seem to concur that both abstract and direct observation of role models imply similar entrepreneurial learning outcomes (Fiet 2001; Radu and Loue 2008).

Research also demonstrates that peers (especially school peers, university peers and work colleagues) are observed as entrepreneurial role models. Learning from observing peers is a process informed and developed through social interactions (Pittaway et al. 2011). School peers influence entrepreneurial intentions by providing the basis for a change in identity, 
which relies on accepting an entrepreneurial career as a valuable prospect (Falck, Heblich, and Luedemann 2010). Peer observation is also linked to benefits deriving from social interactions as Pittaway et al. (2015) exemplify in their study on the importance of student clubs. Students attending these extra-curricular activities are able to learn from observing the practices and behaviours of similarly like-minded individuals. The effect of observing university peers as role models would seem to be enduring (Kacperczyk 2012) and is linked to developing creative entrepreneurial ideas (Gemmell, Boland, and Kolb 2011). Empirical evidence on a distinct type of peer, namely, work colleagues, suggests similar conclusions. Observing work colleagues enacting entrepreneurial practices and behaviours based on their experiences seems to have a strong effect on the entrepreneurial intentions and motivations of colleagues (Nanda and Sorensen 2010).

The critical analysis of this literature highlights two important issues overlooked by previous studies. First, research has broadly investigated the outcomes of observing role models in relation to entrepreneurial career selection (e.g., increasing entrepreneurial intentions and motivations), however, very little is said about the specific learning tasks associated with observing role models. Thus, we argue that this focus on entrepreneurial career outcomes is likely to provide only partial insights into how observing role models is associated with entrepreneurial learning. Second, while prior research has developed extensive understanding on the learning relationship between entrepreneurs and specific groups of role models (e.g., parents, peers, workplace colleagues), it implicitly assumes that the overall observation process remains unchanged. This is surprising, since observing role models is thought to be contextual and influenced by multiple environmental variables (Holcomb et al. 2009; Sardana and Scott-Kemmis 2010). We argue that a greater understanding of the context in which observations occur is likely to enable further 
developing what is known about the influence of role models on the entrepreneurial learning process.

In sum, our study draws on and extends the work of Cope $(2005,390)$ who urges researchers to further "comprehend whom prospective entrepreneurs learn from and with prior to start-up, and also what they learn from these social interactions' by conducting indepth investigations of the processes and outcomes of observing role models and how this affects entrepreneurial learning.

\section{Method}

Through our research questions, we attempt to offer a richer perspective on the processes associated with observing role models and the entrepreneurial learning outcomes deriving from these observations. Our approach is interpretive and inductive, and purposefully designed to generate understanding on the experiences of participants and the situations they encountered (Gephart 2004; Jaskiewicz et al. 2015; Marshall and Rossman 2006). This entails taking into account Wang and Chugh's (2014) recent observations on the importance of a qualitative approach in developing studies on entrepreneurial learning. This also enables building in-depth understanding of how participants articulate the types of interactions and how these specifically affected their learning.

\section{Sample and data collection}

Purposeful sampling (Denzin and Lincoln 2000; Patton 2002; Pratt 2009) enabled the lead researcher to identify sixteen participants through academic links. All participants attended a programme delivered by a top-rated UK university aimed specifically at entrepreneurs. Previous studies show that using a sample of entrepreneurs with links to universities can be critical to generating insights into entrepreneurial learning (Gordon, Hamilton, and Jack 2012). The decision to use this group as our sample was also based on the recognition that 
building in-depth understanding on learning journeys and role models requires a high level of trust between the lead researcher and the participants. Previous experience has also taught us that this type of programme provides a forum for building such trust (Gordon et al. 2012; Kempster and Cope 2010).

Our sample includes a mix of entrepreneurs from new and established businesses, a range of personal backgrounds and different business activities and configurations. Table 1 provides details of the participants and their businesses (for reasons of anonymity, their names, role models, businesses and specific details relating to the location of participants are not reported).

Insert Table 1 about here

A life course approach is used to generate the data (Giele and Elder 1998b; O'Rand 1998), which is considered appropriate when investigating the intersection between life, learning from social interactions, observing role models and temporal sequence (Levinson 1986). Our view is that adopting a life course approach enables developing in-depth understanding of how observing role models affects the past, helps make sense of the present and shapes future expectations and motivations (Belli, Alwin, and Stafford 2009; Giele and Elder 1998b).

A life course approach offers a substantially different and more contemporary understanding than the life cycle view. While life cycle studies assume that individuals go through fixed stages at different ages (Green 2010), the life course approach analyses particular life trajectories. The life cycle concept implicitly assumes that at certain stages individuals tend to develop common decision-making processes leading to similar outcomes. In contrast, life course scholars argue that decisions that individuals make tend to be contextualised taking into account, for example, social interactions, such as the influence of role models. In sum, from an interpretative stance (Scott and Alwin 1998), life course 
scholars investigate complex issues associated with distinct individual trajectories that are rarely clear, linear or repeated across large cohorts of individuals and generations (Green 2010). For instance, entrepreneurship scholars use distinct life course approaches to understand how entrepreneurial motivations affect individual life courses (Jayawarna, Rouse, and Kitching 2011), how social contexts affect the resources available for start-ups (Jayawarna, Rouse, and Macpherson 2014) and how gender variations may affect business growth (Davis and Shaver 2012). The insights from these life course studies coupled with the suggestions of researchers investigating similar topics (Kempster 2009; Rae and Carswell 2000; Taylor and Thorpe 2004) inform our life course approach to further understand how role models affect entrepreneurial learning.

In essence, we: 1) identified the terms that reflect 'role models' for participants, namely, 'significant person', 'important person' and 'inspiration'; 2) we tested these terms through a pilot study designed to ensure the appropriateness of our life course approach and a fit with the understanding, situations and context of the experiences of individual entrepreneurs. The pilot study consisted in two sets of group interviews where the researcher and participants discussed ways of prompting dialogue on role models; 3) the research team discussed the pilot interview to ensure the best terminology to generate the type and depth of data sought from the main study. Confident with the outcomes of the pilot study, we then proceeded to generate chronological and systematic data across the sample. The data from each participant was then collected by the lead researcher in two key stages.

Stage 1 consisted in inviting the participants to draw a role model encounter timeline (Clausen 1998; Martyn 2009) and chronologically articulate the 'most significant people' in their entrepreneurial journey (Kempster 2009; Rae and Carswell 2001). Asking participants to recall the 'most significant people' enabled capturing their 'continuous social learning cycles' and the details underpinning their role models (Rae and Carswell 2000, 224). 
To focus participants on identifying people rather than significant events, we encouraged them to concentrate on the individuals but also to reflect on the impact they had on their learning experiences. The participants were given approximately an hour to complete this task (in silence and in isolation from other participants to allow them to be as focused and dedicated as possible) including as many details as possible on the individuals in question. Prior studies show that timelines can be critical in providing comprehensive autobiographical accounts (Taylor and Thorpe 2004) while at the same time allowing participants a high degree of flexibility on what they share (Clausen 1998).

Stage 2 involved interviewing participants in-depth about their encounter timelines. The research team purposefully decided against interviewing participants immediately after completing the timeline to allow time for reflection and build further trust and rapport between the lead researcher and the participants (Edwards 1993; Renzetti and Lee 1993) through various events, masterclasses and general training sessions. The interviews were conducted four to five months after the timeline exercise. By this time, all participants had a good relationship with the lead researcher. This also seemed to influence the amount of data gathered, which we believe was more extensive than would have been the case had it been collected earlier.

We adopted the life course interviewing principles (Martyn 2009; Martyn and Belli 2002) with interviews structured in two different parts (see Appendix 1 for the interview script). Each interview began with the researcher providing a brief presentation of the research topic and ensuring participants had their encounter timelines available. The first part of the interview entailed asking background questions about the entrepreneur, the business and the overall entrepreneurial context. Thereafter, the interview focused on the timeline. Each participant was probed on the individuals they included in their timelines and invited to explain and expand on how these individuals were linked to their learning process. 
Consistent with life course interviewing, the participants were also encouraged to articulate significant information about each role model (Giele and Elder 1998a). The interviews ended by asking participants if they would like to add further role models to their timeline. Thirteen participants chose to add one or two role models. At the end of the interview, the researcher asked permission to photograph the encounter timeline (permission was granted in all but four cases).

The interviews were recorded (Mason 2002) and lasted an average 90 minutes, with a minimum of 30 and a maximum of 120 minutes. In total, 203 learning observations from role models were articulated as significant in the participants' entrepreneurial trajectories. This two-stage approach provided rich and informative data allowing our key research question to be addressed (Chenail 2009; Pratt 2009; Reay 2014).

\section{Data analysis}

The interviews were transcribed verbatim and then combined with relevant notes and observations to provide the raw data. We then began reading and re-reading the data searching for incidents related to learning from role models from the extensive material gathered (Silverman 2000). While this allowed reducing the material, it also helped us to organise it in relation to time and space so we could more clearly identify the links between the role models and learning as well as the relationship between these aspects. The research team took extensive notes, sharing and discussing the issues related to the role models and entrepreneurial learning (no software was employed).

The data was then organised into descriptive categories and explanatory themes by identifying emerging patterns and commonalities explaining the relationship between the role models and learning (Bruton and Ahlstrom 2003; McKeever, Jack, and Anderson 2015; Miles and Huberman 1994), thereby enabling addressing our research question (Eisenhardt 1989; McKeever et al. 2015). 
The explanatory themes identified in the data and in literature included entrepreneurial learning across stages, social contexts, the relationships between entrepreneurs and role models, and learning tasks. We iteratively analysed our data for instances that reflected these themes, continuously considering the ideas emerging from the data in light of the theory and in line with literature in a comparative approach (Bansal and Corley 2012; Glaser and Strauss 1967; Jack and Anderson 2002; McKeever, Anderson, and Jack 2014). We thus inductively questioned the data in relation to 'what is going on?' and 'why does it matter?' (McKeever et al. 2015). This interpretative analysis allowed us to generate understanding of the experiences of our participants (Gephart 2004; Suddaby 2006), appreciate the learning interactions, the influence of their role models and how observation affected their entrepreneurial learning over time.

Our findings are described in the following section in line with the suggestions of Bansal and Corley (2012), Pratt (2009) and McKeever et al. (2014) on how qualitative work should be presented.

\section{Findings}

In addressing our research question, we found that while participants had observed a wide range of role models, they tended to be associated with a particular stage of their entrepreneurial trajectory. Furthermore, participants were able to articulate their distinct learning outcomes relating to entrepreneurship through observing their role models in distinct social contexts pre- and post-start-up. This section presents an in-depth account of the participants' articulations of their role model observations in the two stages (see Table 2 for additional examples). 


\section{Observations of role models pre-start-up}

Three main social contexts appear to underpin the pre-start-up observations. Prior to starting their venture, the participants identified as significant role models their parents (home), teachers and fellow students (education), and finally, colleagues in the workplace (work).

For most participants, parents were amongst the first role models mentioned in interviews, often introduced with prominence and significance. For instance, Cecilia stated:

'Another person who has influenced me massively would have to be my mum. My mum worked really, really hard, she went to a prep school and had a fantastic education. And what that did was to instil an institutionalised way of thinking about the fact that you need to get so many GCSEs, so many A levels for such a degree .... and a first class and honours degree and did everything really, really well. It made me think that I had to go down a certain route to succeed' (Cecilia)

Highlighting the importance of this observation, Cecilia describes the way learning from her mother shaped her approach to work. This articulation was common among participants in relation to how observations of parental role models affected the personal and professional values they enacted throughout their lives:

'... the only thing I think I can take from them is the fact that they, you know, believe in the family and family value, integrity and honesty and that kind of thing. That state of mind is how you think you like to do business with integrity, with honesty' (Robert)

'My parents were tremendously supportive... They were very important in terms of a working hard ethic, behaviour patterns, lifetime beliefs and the way of being. So I think they were strongly influential [an example would be] you don't tell lies. You don't tell lies ever' (Fabian) 
As Fabian's statement illustrates, participants often articulated in detail the impact on their overarching learning with particular emphasis attributed to how role models demonstrated important behaviours in relation to a strong work ethic. Matthew noted:

'Mother was a single parent who brought up me and my older sisters while still working full time. [She used to do] 12 hour days while bringing up 3 young children (...) 3 weeks after having me, she was back at work so I think the things I learned from her have been work ethic, I have always been a hard worker, I've never been a clock watcher (...) so I suppose one the key things from her was this work ethic' (Matthew)

These accounts suggest that observation of parental role models helps develop value and belief systems, which are then used to develop both personal and professional values.

Transition into school appears to mark a significant change in observing role models. Entrepreneurs had the possibility of observing numerous teachers and therefore comparing different performances of the same function. They were able to compare role model performances in relation to teaching and these observations were supplemented by how their fellow students reacted to the teachers' behaviours, both positively and negatively.

'... he was violent, he would hit the children, and would always put you down in front of the others. Again nobody liked him and he couldn't get the best out of the children' (Peter)

'... it was a maths teacher, and that would be from around 11 to 16, and he was a very, very positive role model. He was fair, but had sense of humour. He would motivate kids in lessons, he was really good in doing that, and as consequence everyone liked him whereas the PE teacher no one liked' (Peter)

Observations of teachers and colleagues in the school context were also pivotal to understanding how relationships worked and how individuals attempted to manage them. The accounts of relationships were often supplemented with participants' views on how these 
contributed or hindered their development. Three examples illustrate this dimension of observing role models at school:

'... he was also the music teacher in the school (...) he spent a lot of time with me because obviously I have a talent for playing the piano. He was also an older guy, even back then, he was kind of an "old school" teacher, (...) firm but fair with people" (Roderick)

'... the coaches, they weren't just looking at the best player, it wasn't just about your personal performance, it was also about how you got others to perform' (John)

'... very good at her job, very focused, very customer service oriented, nothing was too small for her to organise and do for you... we used to have a rota at the college when I was 16 and sometimes you would be chef de partie, sometimes wine waiter, and then on the rota once every 3 or 4 months you would be head waiter. And quickly a lot of people just said this lady was a real dragon, but for me she was just excellent at her job... and I ended up being head waiter more times that I should have been because people kept asking me to do it and I was good at it (...) I realise that people in my life are quite important to me' (Ray)

As seen, observations of role models in this particular social context led to an appreciation of how relationships become central to the development of particular opportunities and obtaining the best performance from people. Indeed, these descriptions also suggest that understanding the relationships acquired in the school context provides important learning opportunities on managing relationships between peers and others, and how these can develop for personal benefits.

Participants often included observations of role models in a workplace context after leaving school but prior to entrepreneurship. Participants worked in a variety of contexts including small, medium and large organisations. Observations of direct line managers, 
directors or entrepreneurs dominate the illustrations of learning in this social context. Many of the role models identified within the workplace were described as displaying behaviours that either effectively enacted people management skills or specifically lacked such skills.

Describing their observations, participants often illustrated the link between the leader of the organisation, their staff management and how this affected the organisation. Kiki explained:

'... one of my supervisors there was a really big inspiration, she was able to draw out the best in everybody but at the same time acknowledge the things that people might not be so good at. I learned a lot from her about not setting people up to fail' (Kiki)

Understanding the importance of managing people was echoed by Bruno when observing his father at work:

'... the way he deals with people, he never shouts at them, but he gets a lot of respect because most people really like him, he seems like a nice guy and he can be ruthless if he needs to be ruthless' (Bruno)

Participants also observed role models who did not positively affect the workforce. Indeed, multiple examples were offered of role models who were perceived as lacking people management skills and behaviours seen as detrimental to their staff. Roderick explained:

'... and everybody is so demotivated because... he is really big on not giving anybody authority or responsibility but then giving blame for not doing what in his mind they should have done' (Roderick)

While these role models were often regarded as detrimental to staff, the observation of such behaviours was of particular significance to learning how such behaviours can affect the effectiveness of any organisation. Matthew illustrates this learning connection: 
'Not a good person to work for. Kept coming in throwing hand grenades... with the fall out on the people that were left behind... to be honest, not a person I would try to emulate at all' (Matthew)

The workplace also allowed entrepreneurs to observe a number of business-related practices. Participants articulated some unexpected actions of role models leading to outstanding outcomes, for example:

'... he would always make sure that when you found a CV to contact the client straight away. He was really proactive. I say that to my team, don't wait for the customer to come back to us, do your job, sell it to them' (Phil)

'Everyone that worked for him ended up setting up their own business. Because he showed them how easy it was... That's one thing I have tried not let people understand' (Max)

The examples that Phil and Max offer suggest that role model observations in the workplace significantly affect future entrepreneurial behaviours. These accounts of observational learning from role models in the workplace would seem to be linked to continuing and refining the individual's formative process towards entrepreneurship. Most participants reported that observational learning was mostly a source of understanding the professional context, interactions in the workplace and access to best practices. Table 2 summarises learning from observing role models prior to start-up.

Insert Table 2 about here

\section{Observations post-start-up}

The accounts suggest that observational learning from role models post-start-up relate to three social contexts. Our findings show that at this stage, entrepreneurs observe role models 
in the domestic setting (either parents or partners), in the workplace (business partners and staff) and seek out other entrepreneurs as role models.

A wide variety of behaviours was reported post-start-up. Following the decision to engage in entrepreneurship, individuals appear to observe parents and/or partners as role models. The close relationship between the entrepreneur and role model generates observations that participants articulated as noteworthy and meaningful. Eamon explained:

'Mum used to go to this yoga thing at the weekend... So I'll go for a Yoga class and see how that works. It's been fantastic, really enjoy it. It's just like a safety valve; you can just release some air' (Eamon)

The accounts also describe a number of behaviours observed in close role models demonstrating their partner's support for their entrepreneurial decisions. Cecilia and Bruno illustrate this supportive behaviour:

'We have a life like this, maybe we are alright, we don't know! Maybe we are off track, we don't know! He is so positive, hence always encouraged me to be what he believes is right for me and this is right for me' (Cecilia)

'My dad has always had his own businesses. And I think that is where my inner drive came from because I was always encouraged to go that way. He was a partner at Century 21 estate agency, so hence the background, sold out to a big bank when he was about 30 and started a construction company building new houses (...) He has always been an advocate of taking risks because the rewards are much greater (...) I actually thrive like that' (Bruno)

These accounts suggest that the role model's behaviour supports the entrepreneurs in dealing with everyday pressures while offering reassurance in their entrepreneurial career decisions. 
The participants also reported learning from observing role models in their business, commonly from business partners or staff and related to the entrepreneurial firm and its development. Many articulated how business partners functioned as role models who demonstrated complementary behaviours to those of the entrepreneur. Max explained:

'Some of the customers I find irritating; I would say get lost. He doesn't, he stays calm and he is very good with this type of customer' (Max)

Within the business context, numerous examples of role model behaviours were offered that helped participants learn to improve performance in specific functional areas of the organisation. Eamon described how Anthony, a salesman, enacted a significant behaviour in relation to maintaining customer satisfaction:

'... what I have taken from him is just to know when to say no. Basically know your power position and your dynamic. Being a lot more reflective of where you are positioned in relation to customers and a dealer network' (Eamon)

In a similar example, Matthew described how his business partner demonstrated new ways of recruiting top talent to his organisation:

'... what he does, which is a great gift, is that he brings people into his business who have those skill, rather than a lot of people who don't have a good education being envious or jealous or have a chip on their shoulder because of that, he embraces it' (Matthew)

These examples suggest that observation of partners or colleagues in the business context generates impactful learning for the entrepreneur and potential improvements in functional areas of the business.

Finally, participants also articulated that they engage in observing role models who are active entrepreneurs in various industries of different sizes and enjoying variable degrees of success. One of the most observed behaviours is a role model's attitude in relation to their 
business. Max describes an attitude that is contrary to what he believes can generate a successful entrepreneurial endeavour:

'That $P$ had a unit near us, he had no idea of promoting or selling, he couldn't do accounts, he just wasn't interested in the business. I think he only set it up so he didn't have to work for somebody else. He never made money and never had money' (Max)

These examples illustrate that observation of these role models creates a sense of reassurance in the decisions and course of actions followed by participants. Cecilia summarises learning generated from observing other entrepreneurs and businesses:

'What you actually learn is that they have the same problems you have, no matter what size they are... I found that certain things that I've learnt are just about confidence and a belief' (Cecilia)

Particularly significant is that by observing similar entrepreneurs, insight is gained on the most effective way of exploiting entrepreneurial opportunities. John and Robert asserted:

'... he is the director of a brewery in L. He actually has the perfect setup. Their brewery is $99 \%$ owned by one person. Down there, they've got a proven formula for family succession in the business. There is only one family member who is going to be the boss, that's it, and they are chosen from early age' (John)

'... he said this is my third recession, just cut costs. I am still here and I will still be here after this recession; cut costs, batten down the hatches, and come out the other side' (Robert)

As the participants stated, the outcomes of observational learning are not confined to a specific functional area of the business and often reflect small improvements that enhance performance in the organisation. The participants also articulated behaviours that, by going beyond their understanding of available solutions, triggered what appears to be significant learning. The descriptions provided in this context suggest that learning opportunities are 
preceded by an identification process where participants discover additional information on the role model. This identification process would also seem to facilitate observational learning. In addition to the discussion above, Table 2 summarises observational learning poststart-up.

\section{Interpretation and analysis}

Extending the work of Gibb (1997) on the 'learning environment', this research underlines the significance of the social context in observing role models and how this affects entrepreneurial learning. Our findings suggest that entrepreneurs do not learn merely from being exposed to role models, but more significantly, they learn from observing role models in distinct social contexts. Moreover, our findings suggest that observing role models in distinct social contexts is intrinsically related to the pre- and post-start-up entrepreneurial stages.

\section{Distinguishing the nature of observations pre- and post-start-up}

We demonstrate that prior to start-up, most observations were unpremeditated and unplanned. While these observations appear to be central to the individual's development, the participants' accounts underline that they were prompted by sharing a setting with a prominent or recurrent role model (Bosma et al. 2012; Hoffmann et al. 2015). This tells us that role modelling prior to start-up is underpinned by multiple and frequent contacts leading to strong relationships that in turn facilitate further role modelling and enhance future observations.

While this focus on the presence and characteristics of role models is well established in entrepreneurship literature (Bosma et al. 2012; Mungai and Velamuri 2011; Scherer et al. 1989), our study demonstrates that role modelling prior to start-up is also based on the human interaction within the particular social context (Bandura 1977), such as the home or school. 
Moving beyond the where and how, this study demonstrates that observing role models in different contexts prior to start-up contributes to learning associated with specific learning tasks according to Cope (2005). Extending previous studies adopting an experiential stance (Cope 2005; Harvey and Evans 1995), this study shows that the observation of role models is associated with fundamental entrepreneurial learning tasks (Cope 2005), such as learning about oneself, understanding and managing relationships, and the initial stock of learning concerning the management of small businesses. Our study also echoes the insights of Cope (2001) showing that the acquisition of pre-start-up learning tasks is a long process that occurs in multiple social contexts rather than those immediately accessed prior to start-up.

Figure 1 summarises our theoretical understanding of how subsequent observation of role models in distinct social contexts prior to start-up is underpinned by specific observation processes associated with particular learning tasks for the entrepreneur.

Insert Figure 1 about here

Having discussed pre-start-up learning, we now move to the post-start-up findings. In this regard, we show that starting a new venture appears to propel entrepreneurs to using their observational opportunities in a more purposeful way. Post-start-up, the participants illustrate that observation contributed to their own learning needs as well as those of the venture.

Our findings suggest that learning through observation is closely associated with how entrepreneurs learn when dealing with personal or entrepreneurial problems and challenges (Sexton et al. 1997; Young and Sexton 1997). Searching for potential solutions to deal with these challenges, the nature of observing role models post-start-up changes substantially to a dynamic configuration where distinct social contexts are accessed to enact observational 
learning. Dealing with diversified and concurrent challenges, entrepreneurs scan multiple social contexts and role models in search of potential solutions.

Our findings demonstrate that these entrepreneurial challenges affect the process through which role models are selected. In line with prior literature, we also find that role models are usually found in the entrepreneur's close networks (Bosma et al. 2012). Role models perceived as having achieved high performance behaviours in their personal and professional endeavours are purposefully observed and engaged. This is an important addition to literature focusing on the behaviours of role models (Bosma et al. 2012) albeit neglecting how role modelling is linked to the personal and professional challenges faced along the entrepreneurial journey.

In relation to the entrepreneurial learning tasks proposed by Cope (2005), our findings suggest that entrepreneurs learn mostly about themselves, the external business environment and small business management. By comparing their own behaviours with post-start-up role models, entrepreneurs find better ways of dealing with their own personal challenges and specific areas of the business where they can improve and critically observe behaviours that lead to high performance in others.

Insert Figure 2 about here

Figure 2 summarises our understanding of how role models are observed post-start-up. Given specific problems or entrepreneurial challenges, entrepreneurs simultaneously access multiple social contexts in the pursuit of potential solutions.

\section{Observation of role models and entrepreneurial learning}

Research widely demonstrates that exposure and observation of role models contributes to the development of entrepreneurial self-efficacy and motivations (Radu and Loue 2008; Scherer 
et al. 1989; Van Auken et al. 2006). However, less appears to be known about the processes with which role models are selected and subsequently observed (Bosma et al. 2012). As an example, Cope (2005) argues that more work should focus on understanding with whom, how and what is learned from social interactions with role models. While Cope (2005) is particularly interested in how learning from observing role models influences preparedness for entrepreneurship, we consider it equally important to understand how entrepreneurs continue to observe role models in the context of leading their ventures post-start-up (Lans et al. 2008).

The findings suggest that role model observation occurs in different social contexts accessed pre- and post-start-up. Particularly interesting is that our study suggests a link between interpersonal attraction and the selection of role models for each of these contexts. Thus, this study shows that the processes of observing role models are distinct pre- and poststart-up and based on the different social contexts the entrepreneur accesses. In line with this finding, our study also shows that entrepreneurs learn about distinct learning tasks at each stage. While pre-start-up observations appear to trigger understanding of developing a personal and entrepreneurial value and belief system as well as social relationships and small business management, post-start-up observations lead to outcomes linked to personal and entrepreneurial development. Our argument, as depicted in the distinct characteristics of our pre- and post-start-up theoretical models (Figures 1 and 2), is that the social contexts, processes and learning tasks accrued from observations in these two stages are substantially distinct in relation to these dimensions.

In view of the evolving nature of observing role models in entrepreneurship, our study contributes to entrepreneurial learning literature as follows.

We show that role modelling is equally important for entrepreneurial learning pre- and post-start-up. Indeed, we show that entrepreneurial learning continues to be associated with 
observing role models although through distinct learning processes and learning tasks. We address calls for greater understanding of how, when and where entrepreneurs learn as part of their preparation for entrepreneurship (Cope 2005) showing that entrepreneurs learn from observing role models in a multitude of social contexts through distinct mechanisms that are in turn associated with particular learning tasks essential to start-up. Moreover, we extend previous studies that mainly focus on the influence of role models at start-up (Mungai and Velamuri 2011; Scherer et al. 1989) by exploring role models beyond start-up. In this regard, we show that role models are particularly important to accelerate the search for potential solutions to personal or entrepreneurial challenges. Thus, we complement previous approaches to entrepreneurial learning considering learning from experience as critical to entrepreneurial problem solving (Young and Sexton 1997) by developing understanding of how social learning can provide alternatives to entrepreneurial problem solving.

In addition, we show that learning tasks are associated with observing role models. In this regard, we extend the work of Cope (2005) on the content dimension of entrepreneurial learning showing that observing role models contributes to key learning tasks in entrepreneurship. Specifically, we show that learning about oneself, about the business, about relationships and small business management can ensue from observing role models. In providing insights on entrepreneurial learning tasks as outcomes of observation, we complement prior research that largely considers the role of experiences and experiential learning in the formation of these tasks (Cope 2005; Pittaway and Thorpe 2012).

Overall, we extend current understanding of contextualised entrepreneurial learning (Gabrielsson and Politis 2012; Politis 2005; Reuber and Fischer 1999) suggesting that learning from observing role models is specific to each context accessed by the entrepreneur. This study confirms Holcomb et al.'s (2009) conceptual suggestion that the entrepreneurial learning processes and outcomes are specific to and vary across social contexts. By accessing 
distinct contexts, entrepreneurs learn about a range of entrepreneurial practices. In developing in-depth understanding of how each context contributes to the overall process and practices, this paper responds to Wang and Chugh's (2014) call urging researchers to develop understanding at the intersection of learning and entrepreneurship.

\section{Conclusions}

Calls have been made for work that continues the development of entrepreneurial learning from a contextualised and situated perspective (Cope 2011; Hamilton 2011; Sardana and Scott-Kemmis 2010). We respond to these calls by generating knowledge on how entrepreneurs learn from others, specifically from observing role models. In addressing the overarching question: 'How do entrepreneurs learn from observing role models?' we also considered two sub-questions. The first relates to the social context: 'Where and how are role models observed?'. The second relates to the content of entrepreneurial learning: 'What is learned from observing role models?'. We show that entrepreneurs navigate through different social contexts to generate insightful and effective observations relevant to their own development and the management of their entrepreneurial venture. Underpinned by a life course approach, we demonstrate an important link between the venture creation stage and the social contexts associated with observing role models. Pre-start-up, entrepreneurs learn mostly from unplanned learning interactions with a wide range of role models who contribute to the development of their professional self (Gibson 2004). In contrast, the post-start-up observation of role models appears to be purposeful and linked to personal or business challenges. This paper also demonstrates that observations in multiple contexts accessed by entrepreneurs pre- and post-start-up contribute to the development of distinct entrepreneurial learning tasks (Cope 2005).

Overall we contribute to developing understanding of how entrepreneurs learn from observing others (Bosma et al. 2012; Hoffmann et al. 2015), showing that observing role 
models in distinct social contexts is associated with learning tasks essential to entrepreneurship.

\section{Implications for entrepreneurship educators}

The findings of this study emphasise that role models support learning associated with specific entrepreneurial learning tasks along the entrepreneurial journey. Indeed, this study posits that individuals have learned and continue to learn complex practices and behaviours over time (Bosma et al. 2012) from observing role models. In doing so, it carries implications for educators dedicated to enterprise education.

Based on the core insights of this paper, enterprise educators working with students prior to start-up may consider creating curriculum activities that require students to shadow entrepreneurs and reflect on the practices they observe. Taking this exercise further, educators could, for example, ask students to conduct shadowing exercises (Roan and Rooney 2006) with multiple entrepreneurs over the duration of their degree. The evidence in our study suggests that the opportunity to observe distinct entrepreneurs will provide students with understanding of the benefits of observation as well as enhancing the acquisition of entrepreneurial learning tasks.

For enterprise educators working towards developing entrepreneurs, our study shows that entrepreneurs continue to consider observation as a way of developing themselves and their businesses. For example, post-start-up, our findings show that entrepreneurs can locate solutions for their learning needs within their business through observing business partners or members of staff. This implies that observations within the business are equally important to acquiring and updating learning tasks and should be encouraged by entrepreneurship educators.

Taken together, our study demonstrates the importance of observing role models for the acquisition of learning tasks essential to the start-up and development of the entrepreneurial 
venture. Overall, this implies the relevance of continuing to observe at all stages of the entrepreneurial journey. As a consequence, our work suggests that entrepreneurship educators could consider including both reflective and active elements of observing role models in activities with entrepreneurs. According to our study, such educational practices would support entrepreneurs in recalling, valuing and learning from past observations, as well as triggering new observations of role models. 


\section{References}

Bandura, A. 1977. Social Learning Theory. Prentice Hall.

Bansal, P., and K. Corley. 2012. "Publishing in AMJ - Part 7: What's Different about Qualitative Research?" Academy of Management Journal 55 (3): 509-513. doi:10.5465/amj.2012.4003.

Belli, R. F., D. F. Alwin, and F. P. Stafford. 2009. Calendar and Time Diary: Methods in Life Course Research. London: Sage.

Belli, R. F., and M. Callegaro. 2009. "The Emergence of Calendar Interviewing: A Theoretical and Empirical Rationale." In Calendar and Time Diary: Methods in Life Course Research, edited by R. F. Belli, D. F. Alwin, and F. P. Stafford. London: Sage.

Bosma, N., J. Hessels, V. Schutjens, M. Van Praag, and I. Verheul. 2012. "Entrepreneurship and Role Models." Journal of Economic Psychology 33 (2): 410-424. doi:10.1016/j.joep.2011.03.004.

Boyd, N. G., and G. S. Vozikis. 1994. "The Influence of Self-Efficacy on the Development of Entrepreneurial Intentions and Actions.” Entrepreneurship Theory and Practice 18: 6377.

Bruton, G. D, and D. 2003. “An Institutional View of China's Venture Capital Industry." Journal of Business Venturing 18 (2): 233-259. doi:10.1016/S0883-9026(02)00079-4.

Chenail, R. J. 2009. “Communicating Your Qualitative Research Better.” Family Business Review 22 (2): 105-108. doi:10.1177/0894486509334795.

Clausen, J. 1998. "Life Reviews and Life Stories." In Methods of Life Course Research: Qualitative and Quantitative Approaches, edited by J. Z. Giele and G. H. Elder, 189-212. Thousand Oaks: SAGE.

Cope, J. 2001. “The Entrepreneurial Experience: Towards a Dynamic Learning Perspective of Entrepreneurship.” Unpublished Doctoral Thesis, Lancaster: Lancaster University. 
Cope, J. 2005. "Toward a Dynamic Learning Perspective of Entrepreneurship." Entrepreneurship Theory and Practice 29 (4): 373-397. doi:10.1111/j.15406520.2005.00090.x.

Cope, J. 2011. "Entrepreneurial Learning from Failure: An Interpretative Phenomenological Analysis." Journal of Business Venturing $26 \quad$ (6): 604-623. doi:10.1016/j.jbusvent.2010.06.002.

Davis, A. E., and K. G. Shaver. 2012. "Understanding Gendered Variations in Business Growth Intentions Across the Life Course.” Entrepreneurship Theory and Practice 36 (3): 495-512. doi:10.1111/j.1540-6520.2012.00508.x.

Denzin, N. K., and Y. S. Lincoln. 2000. Handbook of Qualitative Research. 2nd ed. SAGE.

Dunn, T., and D. Holtz-Eakin. 2000. "Financial Capital, Human Capital, and the Transition to Self-Employment: Evidence from Intergenerational Links.” Journal of Labor Economics 18 (2): 282-305. doi:10.1086/209959.

Edwards, R. 1993. “An Education in Interviewing.” In Researching Sensitive Topics, edited by C. M. Renzetti and R. M. Lee, 181-196. Newbury Park, California: Sage Publications. Eisenhardt, K. M. 1989. "Building Theories from Case Study Research.” Academy of Management Review 14 (4): 532-550.

Erikson, T. 2003. "Towards a Taxonomy of Entrepreneurial Learning Experiences among Potential Entrepreneurs.” Journal of Small Business and Enterprise Development 10 (1): 106-112. doi:10.1108/14626000310461240.

Falck, O., S. Heblich, and E. Luedemann. 2010. "Identity and Entrepreneurship: Do School Peers Shape Entrepreneurial Intentions?" Small Business Economics 39 (1): 39-59. doi:10.1007/s11187-010-9292-5.

Fiet, J. O. 2001. “The Theoretical Side of Teaching Entrepreneurship.” Journal of Business Venturing $16(1): 1-24$. 
Gabrielsson, J., and D. Politis. 2012. "Work Experience and the Generation of New Business Ideas among Entrepreneurs: An Integrated Learning Framework.” International Journal of Entrepreneurial Behaviour \& Research $18 \quad$ (1): 48-74. doi:10.1108/13552551211201376.

Gemmell, R. M., R. J. Boland, and D. A. Kolb. 2011. "The Socio-Cognitive Dynamics of Entrepreneurial Ideation.” Entrepreneurship Theory and Practice 36 (5): 1053-1073. doi:10.1111/j.1540-6520.2011.00486.x.

Gephart, R. P. 1999. "Paradigms and Research Methods.” Research Methods Division (AoM). http://division.aomonline.org/rm/1999_RMD_Forum_Paradigms_and_Research_Method s.htm.

Gephart, R. P. 2004. "Qualitative Research and the Academy of Management Journal." Academy of Management Journal 47 (4): 454-462. doi:10.5465/AMJ.2004.14438580.

Gibb, A. 1997. "Small Firms' Training and Competitiveness. Building Upon the Small Business as a Learning Organisation.” International Small Business Journal 15 (3): 1329. doi:10.1177/0266242697153001.

Gibson, D. E. 2004. "Role Models in Career Development: New Directions for Theory and Research.” Journal of Vocational Behavior 65 (1): 134-156.

Giele, J. Z., and G. H. Elder. 1998a. Methods of Life Course Research: Qualitative and Quantitative Approaches. Thousand Oaks, California: Sage Publications.

Giele, J. Z., and G. H. Elder. 1998b. "Life Course Research: Development of a Field.” In Methods of Life Course Research: Qualitative and Quantitative Approaches, edited by Janet Zollinger Giele and Glen H. Elder. Thousand Oaks, California: Sage Publications.

Glaser, B. G., and A. L. Strauss. 1967. The Discovery of Grounded Theory: Strategies for Qualitative Research. New York: Aldine. 
Gordon, I., E. Hamilton, and S. L. Jack. 2012. "A Study of a University-Led Entrepreneurship Education Programme for Small Business Owner/managers." Entrepreneurship \& Regional Development $24 \quad$ (9-10): 767-805. doi:10.1080/08985626.2011.566377.

Green, L. 2010. Understanding the Life Course: Sociological and Psychological Perspectives. Cambridge; Malden, MA: Polity.

Hamilton, E. 2011. "Entrepreneurial Learning in Family Business: A Situated Learning Perspective." Journal of Small Business and Enterprise Development 18 (1): 8-26. doi:10.1108/14626001111106406.

Hamilton, E. 2013. Entrepreneurship across Generations: Narrative, Gender and Learning in Family Business. Cheltenham, UK; Northampton, MA: Edward Elgar Publishing.

Harvey, M., and R. Evans. 1995. "Strategic Windows in the Entrepreneurial Process." Journal of Business Venturing 10 (5): 331-347. doi:10.1016/0883-9026(95)00037-9.

Hoffmann, A., M. Junge, and N. Malchow-Møller. 2015. "Running in the Family: Parental Role Models in Entrepreneurship." Small Business Economics 44 (1): 79-104. doi:10.1007/s11187-014-9586-0.

Holcomb, T. R., R. D. Ireland, R. M. Holmes Jr., and M. A. Hitt. 2009. "Architecture of Entrepreneurial Learning: Exploring the Link Among Heuristics, Knowledge, and Action." Entrepreneurship Theory and Practice 33 (1): 167-192. doi:10.1111/j.15406520.2008.00285.x.

Jack, S. L., and A. R. Anderson. 2002. "The Effects of Embeddedness on the Entrepreneurial Process.” Journal of Business Venturing 17 (5): 467-487.

Jaskiewicz, P., J. G. Combs, and S. B. Rau. 2015. “Entrepreneurial Legacy: Toward a Theory of How Some Family Firms Nurture Transgenerational Entrepreneurship." Journal of Business Venturing 30 (1): 29-49. doi:10.1016/j.jbusvent.2014.07.001. 
Jayawarna, D., J. Rouse, and J. Kitching. 2011. "Entrepreneur Motivations and Life Course." International Small Business Journal 31 (1): 34-56. doi:10.1177/0266242611401444.

Jayawarna, D., J. Rouse, and A. Macpherson. 2014. "Life Course Pathways to Business StartUp.” Entrepreneurship \& Regional Development 26 (3-4): 282-312. doi:10.1080/08985626.2014.901420.

Kacperczyk, A. J. 2012. "Social Influence and Entrepreneurship: The Effect of University Peers on Entrepreneurial Entry." Organization Science 24 (3): 664-683. doi:10.1287/orsc.1120.0773.

Kempster, S. 2009. “Observing the Invisible: Examining the Role of Observational Learning in the Development of Leadership Practice." Journal of Management Development 28 (5): 439-456. doi:10.1108/02621710910955976.

Kempster, S., and J. Cope. 2010. "Learning to Lead in the Entrepreneurial Context." International Journal of Entrepreneurial Behaviour \& Research 16 (1): 5-34. doi:10.1108/13552551011020054.

Konopaski, M., S. L. Jack, and E. Hamilton. 2015. "How Family Business Members Learn About Continuity." Academy of Management Learning \& Education 14 (3): 347-364. doi:10.5465/amle.2014.0244.

Lafuente, E., Y. Vaillant, and J. Rialp. 2007. "Regional Differences in the Influence of Role Models: Comparing the Entrepreneurial Process of Rural Catalonia." Regional Studies 41 (6): 779-796. doi:10.1080/00343400601120247.

Lans, T., H. Biemans, J. Verstegen, and M. Mulder. 2008. "The Influence of the Work Environment on Entrepreneurial Learning of Small-Business Owners." Management Learning 39 (5): 597-613. doi:10.1177/1350507608098117.

Levinson, D. J. 1986. “A Conception of Adult Development.” American Psychologist 41 (1): 3-13. doi:10.1037/0003-066X.41.1.3. 
Marshall, C., and G. B. Rossman. 2006. Designing Qualitative Research. 4th ed. Thousand Oaks, California: Sage Publications.

Martyn, K. 2009. “Adolescent Health Research and Clinical Assessment. Using SelfAdministered Event History Calendars." In Calendar and Time Diary: Methods in Life Course Research, edited by R. F. Belli, D. F. Alwin, and F. P. Stafford. London: Sage.

Martyn, K, and R. F. Belli. 2002. "Retrospective Data Collection Using Event History Calendars." Nursing Research 51 (4): 270-274.

Mason, J. 2002. Qualitative Researching. Sage Publications.

McKeever, E., A. R. Anderson, and S. L. Jack. 2014. "Entrepreneurship and Mutuality: Social Capital in Processes and Practices." Entrepreneurship \& Regional Development 26 (5-6): 453-477. doi:10.1080/08985626.2014.939536.

McKeever, E., S. Jack, and A. Anderson. 2015. "Embedded Entrepreneurship in the Creative Re-Construction of Place.” Journal of Business Venturing 30 (1): 50-65. doi:10.1016/j.jbusvent.2014.07.002.

Miles, M., and A. M. Huberman. 1994. Qualitative Data Analysis: A Source Book of New Methods. Beverly Hills, CA: Sage Publications.

Mungai, E., and S. R. Velamuri. 2011. "Parental Entrepreneurial Role Model Influence on Male Offspring: Is It Always Positive and When Does It Occur?" Entrepreneurship Theory and Practice 35 (2): 337-357. doi:10.1111/j.1540-6520.2009.00363.x.

Nanda, R., and J. B. Sorensen. 2010. "Workplace Peers and Entrepreneurship.” Management Science 56 (7): 1116-1126. doi:10.1287/mnsc.1100.1179.

O'Rand, A. M. 1998. "The Craft of Life Course Studies." In Methods of Life Course Research: Qualitative and Quantitative Approaches, edited by J. Z. Giele and G. H. Elder, 52-74. Thousand Oaks: SAGE. 
Patton, M. Q. 2002. Qualitative Research and Evaluation Methods. 3rd. Thousand Oaks, CA: SAGE.

Pittaway, L. A., J. Gazzard, A. Shore, and T. Williamson. 2015. "Student Clubs: Experiences in Entrepreneurial Learning." Entrepreneurship \& Regional Development 27 (3-4): 127153. doi:10.1080/08985626.2015.1014865.

Pittaway, L. A., E. Rodriguez-Falcon, O. Aiyegbayo, and A. King. 2011. "The Role of Entrepreneurship Clubs and Societies in Entrepreneurial Learning." International Small Business Journal 29 (1): 37-57. doi:10.1177/0266242610369876.

Pittaway, L. A., and R. Thorpe. 2012. “A Framework for Entrepreneurial Learning: A Tribute to Jason Cope." Entrepreneurship \& Regional Development 24 (9-10): 837-859. doi:10.1080/08985626.2012.694268.

Politis, D. 2005. "The Process of Entrepreneurial Learning: A Conceptual Framework." Entrepreneurship Theory and Practice 29 (4): 399-424.

Pratt, M. G. 2009. "For the Lack of a Boilerplate: Tips on Writing Up (and Reviewing) Qualitative Research.” Academy of Management Journal 52 (5): 856-862. doi:10.5465/AMJ.2009.44632557.

Radu, M., and C. Loue. 2008. "Motivational Impact of Role Models as Moderated by 'Ideal' vs. 'Ought Self Guides.’” Journal of Enterprising Culture 16 (4): 441-465.

Rae, D., and M. Carswell. 2000. "Using a Life-Story Approach in Researching Entrepreneurial Learning: The Development of a Conceptual Model and its Implications in the Design of Learning Experiences." Education + Training 42 (4/5): 220-228.

Rae, D., and M. Carswell. 2001. "Towards a Conceptual Understanding of Entrepreneurial Learning.” Journal of Small Business and Enterprise Development 8 (2): 150-158.

Reay, T. 2014. "Publishing Qualitative Research.” Family Business Review 27 (2): 95-102. doi:10.1177/0894486514529209. 
Renzetti, C. M., and R. M. Lee. 1993. Researching Sensitive Topics. Sage Publications.

Reuber, A.R., and E. Fischer. 1999. "Understanding the Consequences of Founders' Experience.” Journal of Small Business Management 37 (2): 30-45.

Roan, A., and D. Rooney. 2006. "Shadowing Experiences and the Extension of Communities of Practice: A Case Study of Women Education Managers." Management Learning 37 (4): 433-454. doi:10.1177/1350507606070215.

Sardana, D., and D. Scott-Kemmis. 2010. "Who Learns What? A Study Based on Entrepreneurs from Biotechnology New Ventures." Journal of Small Business Management 48 (3): 441-468. doi:10.1111/j.1540-627X.2010.00302.x.

Scherer, R. F., J. S. Adams, S. S. Carley, and F. A. Wiebe. 1989. "Role Model Performance Effects on Development of Entrepreneurial Career Preference.” Entrepreneurship Theory and Practice 13 (3): 53-71.

Scott, J., and D. F. Alwin. 1998. "Retrospective versus Prospective Measurement of Life Histories in Longitudinal Research." In Methods of Life Course Research: Qualitative and Quantitative Approaches, edited by J. Z. Giele and G. H. Elder, 81-97. Thousand Oaks, California: Sage Publications.

Segal, G., J. Schoenfeld, and D. Borgia. 2007. "Which Classroom-Related Activities Enhance Students' Entrepreneurial Interests and Goals? A Social Cognitive Career Theory Perspective." Academy of Entrepreneurship Journal 13 (2): 79-98.

Sexton, D. L., N. B. Upton, L. E. Wacholtz, and P. P. McDougall. 1997. "Learning Needs of Growth-Oriented Entrepreneurs.” Journal of Business Venturing 12 (1): 1-8.

Shepherd, D. A. 2004. "Educating Entrepreneurship Students about Emotion and Learning from Failure." Academy of Management Learning \& Education 3 (3): 274-287. doi:10.5465/AMLE.2004.14242217.

Silverman, D. 2000. Doing Qualitative Research: A Practical Handbook. SAGE. 
Suddaby, R. 2006. "From the Editors: What Grounded Theory Is Not." Academy of Management Journal 49 (4): 633-642.

Taylor, D. W., and R. Thorpe. 2004. "Entrepreneurial Learning: A Process of CoParticipation.” Journal of Small Business and Enterprise Development 11 (2): 203-211.

Van Auken, H., F. Fry, and P. Stephens. 2006. "The Influence of Role Models on Entrepreneurial Intentions." Journal of Developmental Entrepreneurship 11 (2): 157167.

Wang, C. L., and H. Chugh. 2014. "Entrepreneurial Learning: Past Research and Future Challenges: Advancing Entrepreneurial Learning Research.” International Journal of Management Reviews 16 (1): 24-61. doi:10.1111/ijmr.12007.

Young, J. E., and D. L. Sexton. 1997. "Entrepreneurial Learning: A Conceptual Framework." Journal of Enterprising Culture 5 (3): 223-248. doi:10.1142/S0218495897000144. 


\section{Appendix 1}

\section{Interview script}

Initial Protocol - Questions on entrepreneurs/ventures

1. Company/business project - Can you give me a brief description of your company and your specific role?

2. Start-up processes and motivations - When you started your project, what was/were your main motivation/s?

3. Previous background and experience - Can you describe your background and activities prior to starting the company?

4. Decisions and important moments - Can you tell me about important moments in your company's development so far? Proud moments? Main challenges ahead?

\section{$\underline{\text { Timeline Exercise }}$}

5. In our phone call/email, I asked you to bring along your timeline. Can you briefly describe your timeline, highlighting for each person:

a. Why the person is on your timeline

b. What you have learned from them that is significant in the way you operate/run your business today

6. After completing the above task: Would you like to add anyone else to the timeline? Is there anyone else you recall who is not on your timeline and you consider important in relation to the way you run your company today? 
Table 1 Summary of participants' characteristics

\begin{tabular}{|c|c|c|c|c|c|c|}
\hline Participant & Gender & Industry & Age & $\begin{array}{l}\text { Highest level of } \\
\text { education }\end{array}$ & $\begin{array}{c}\text { Entrepreneurial } \\
\text { engagement year }\end{array}$ & $\begin{array}{c}\text { Entrepreneurial } \\
\text { configuration }\end{array}$ \\
\hline Bruno & Male & Energy Services & 26 & University degree & 2007 & SME \\
\hline Cecilia & Female & Internet Trade & 36 & University degree & 2009 & SME \\
\hline Carola & Female & $\begin{array}{l}\text { Entertainment for } \\
\text { Children }\end{array}$ & 40 & $\begin{array}{c}\text { Postgraduate } \\
\text { degree (MBA) }\end{array}$ & 2006 & SME \\
\hline Eamon & Male & $\begin{array}{l}\text { Heavy Machinery } \\
\text { Manufacturing }\end{array}$ & 28 & University degree & 2008 & Family Business \\
\hline Fabian & Male & Financial Services & 57 & $\begin{array}{l}\text { Postgraduate } \\
\text { degree }\end{array}$ & 1993 & SME \\
\hline John & Male & Tourism and Hospitality & 42 & University degree & 1998 & Family Business \\
\hline Kiki & Female & Care & 45 & A Levels & 2005 & SME \\
\hline Matthew & Male & Business Services & 50 & University degree & 2010 & SME \\
\hline $\operatorname{Max}$ & Male & Machinery Manufacturing & 59 & A Levels & 1995 & SME \\
\hline Peter & Male & Financial Services & 44 & University degree & 1994 & SME \\
\hline Phil & Male & Recruitment Services & 30 & A Levels & $\mathrm{n} / \mathrm{a}$ & Family Business \\
\hline Ray & Male & Tourism and Hospitality & 38 & University degree & 1996 & SME \\
\hline Robert & Male & IT & 41 & $\begin{array}{c}\text { University degree, } \\
\text { PGCE }\end{array}$ & 2003 & SME \\
\hline Susan & Female & Manufacturing & 53 & A Levels & 1994 & Family Business \\
\hline Roderick & Male & $\begin{array}{l}\text { Accoustics and Sound } \\
\text { consultancy }\end{array}$ & 38 & $\begin{array}{l}\text { Postgraduate } \\
\text { Degree }\end{array}$ & 2005 & SME \\
\hline Tyler & Male & Financial Services & 47 & University degree & 2004 & SME \\
\hline
\end{tabular}


Table 2 Analytical themes by stage

\begin{tabular}{|c|c|c|c|c|c|}
\hline $\begin{array}{l}\text { Entrepreneurial } \\
\text { stage }\end{array}$ & $\begin{array}{l}\text { Social contexts } \\
\text { (role models } \\
\text { observed) }\end{array}$ & Additional examples from participants & Summarised as & $\begin{array}{l}\text { Emerging themes in } \\
\text { relation to learning tasks } \\
\text { (Cope 2005) }\end{array}$ & $\begin{array}{l}\text { Theoretical } \\
\text { implication for } \\
\text { entrepreneurial } \\
\text { learning } \\
\end{array}$ \\
\hline \multirow{3}{*}{ Pre-start-up } & $\begin{array}{l}\text { Home } \\
\text { (parents, close } \\
\text { family } \\
\text { members) }\end{array}$ & $\begin{array}{l}\text { 'So as a couple, my dad would work all week and my mum wasn't working } \\
\text { because she had the kids, and the kids were young and then she would work } \\
\text { at weekends when my dad was off..., my dad earned the money and my mum } \\
\text { would do everything with it' (Tyler) } \\
\text { 'My mum worked really really hard. She went to a prep school and had a } \\
\text { fantastic education. And what that did was to instil an institutionalised way of } \\
\text { thinking about the fact that you need to get so many GCSEs, so many A } \\
\text { levels...it made me think that I had to go down a certain route to succeed' } \\
\text { (Cecilia) } \\
\text { '... (with my mum) it is just work work work' (Eamon) }\end{array}$ & $\begin{array}{l}\text { Role models provide cues } \\
\text { about establishing right } \\
\text { from wrong }\end{array}$ & $\begin{array}{l}\text { Role model observation } \\
\text { contributes to learning about } \\
\text { oneself by supporting the } \\
\text { creation of a personal system } \\
\text { of values and beliefs }\end{array}$ & \multirow[b]{2}{*}{$\begin{array}{l}\text { Observational } \\
\text { learning from role } \\
\text { models contributes } \\
\text { to specific learning } \\
\text { tasks }\end{array}$} \\
\hline & $\begin{array}{l}\text { Education } \\
\text { (teachers and } \\
\text { colleagues) }\end{array}$ & $\begin{array}{l}\text { '... never made you feel stupid, always told you that you had the ability to do } \\
\text { it, that it would come in the end and he was absolutely right, really got me } \\
\text { through it in the end' (Susan) } \\
\text { '... the headmaster, he was horrendous, he was autocratic, he was hated, he } \\
\text { was detested, and having done my timeline I realised, you know what, I don't } \\
\text { ever want to be like him, he ruled with fear, you know, and we were } \\
\text { frightened of him' (Susan) } \\
\text { I played rugby at school and was made rugby captain; and it was the teacher } \\
\text { who had trust in my ability to actually lead the team. Whether I was a good } \\
\text { player or not. You know, you feel proud that you are out in charge of the team } \\
\text { and recognized for having an ability' (Max) } \\
\text { I was the football team captain so again it was important for me to be a } \\
\text { leader really. And the captaincy of the team... made sure everyone had the } \\
\text { same ideas and how we wanted to be, and motivate people. And really, from a } \\
\text { young age I was looked upon as a bit of leader' (Phil) }\end{array}$ & $\begin{array}{l}\text { By observing different } \\
\text { teachers, entrepreneurs } \\
\text { were able to compare } \\
\text { performances }\end{array}$ & $\begin{array}{l}\text { Role model observation } \\
\text { contributes to an advanced } \\
\text { understanding about } \\
\text { relationships }\end{array}$ & \\
\hline & $\begin{array}{l}\text { Work } \\
\text { (entrepreneurs, } \\
\text { managers, } \\
\text { work } \\
\text { colleagues) }\end{array}$ & $\begin{array}{l}\text { 'A guy called J trained me how to be a sales manager instead of just a } \\
\text { salesman; and how to deal with people. Which is what I am trying to do now' } \\
\text { (Max) } \\
\text { 'If you had a problem... he would actually listen to you and help you' (Peter) } \\
\text { '... deal with the consequences of the people later... it was very task focused' } \\
\text { (Ray) } \\
\text { 'The way he would talk about other people, belittling them and bullying them } \\
\text { in a way. I had never had any experiences of that, but I saw him doing that to } \\
\text { other people' (Kiki) }\end{array}$ & $\begin{array}{l}\text { Role models illustrate } \\
\text { beneficial and detrimental } \\
\text { behaviours related to } \\
\text { people management } \\
\text { Role models demonstrate } \\
\text { unconventional business- } \\
\text { related practices }\end{array}$ & $\begin{array}{l}\text { Role model observation } \\
\text { contributes to learning } \\
\text { about management of } \\
\text { relationships and small } \\
\text { business management }\end{array}$ & \\
\hline
\end{tabular}




\begin{tabular}{|c|c|c|c|c|c|}
\hline & & $\begin{array}{l}\text { 'What I liked about him is that, no matter where he went, he would go up to } \\
\text { every single member of our staff, be it a cleaner, a janitor or the site } \\
\text { manager, shake their hands and ask them whether we, as a company, were } \\
\text { looking after them' (Matthew) } \\
\text { 'She always made the point that if you want someone to change something, } \\
\text { you have to put it in writing, committing yourself completely. Put it in writing } \\
\text { and then follow up, follow up, follow up' (Eamon) }\end{array}$ & & & \\
\hline Post-start-up & $\begin{array}{l}\text { Domestic } \\
\text { setting / home } \\
\text { (parents and } \\
\text { partners) }\end{array}$ & $\begin{array}{l}\text { 'If I start to become too big headed she brings me back to earth, and if I start } \\
\text { to feel down she lifts me up' (Matthew) } \\
\text { 'Parents are in the organizational chart and work... financially your parents } \\
\text { want you to achieve as much as possible' (Carola) } \\
\text { '(Mum) she must have started more businesses that I have dinners, she gets } \\
\text { bored very quickly and I think I have a little bit of both within' (Bruno) } \\
\text { 'If she thinks you're doing something wrong she will tell you. And I think we } \\
\text { all need that from time to time, to keep us on the straight and narrow... I have } \\
\text { become a lot more humble and tolerant of things and more patient' (Matthew) } \\
\text { 'My wife taught me the value of self-confidence,, my wife is } 5 \text { years older than } \\
\text { me (...) I always try to give them a fair chance so they might not be best } \\
\text { friends, but there will be people who don't like me and we just have to accept } \\
\text { the fact that they won't like me for one reason or another and that's just life. } \\
\text { And just be happy! Because life is full of people who like different things, } \\
\text { isn't? So I think she brought that kind of maturity' (Tyler) } \\
\text { 'And I don't think I would be able to do what he has done and maybe he can't } \\
\text { do what I can do now at this stage of moving forward. We bring different } \\
\text { things to the table' (Eamon) } \\
\text { 'We are very different, but very alike... so I am able to take a step back and } \\
\text { perhaps give a different perspective to S. Not in a nasty way, but in a stronger } \\
\text { way, yeah, detached definitely. I am down as sort of being of a different } \\
\text { nature. He is exceptionally patient' (Susan) } \\
\text { 'He will make sure that everyone is looked after... He gives a share of the } \\
\text { profits of the company to all the staff,, from the top managing director, to all } \\
\text { managers, right way through the cooks and the cleaners... he always tells me } \\
\text { that if you invest and you give back you get the most work from them'(Phil) } \\
\text { 'he is actually very good in telling people when they done well, praising you } \\
\text { and he gets, I think he gets a lot of respect for that' (Robert) }\end{array}$ & $\begin{array}{l}\text { Entrepreneurs observe } \\
\text { behaviours that } \\
\text { demonstrate support for the } \\
\text { entrepreneurial decision } \\
\text { Entrepreneurs observe role } \\
\text { models illustrating } \\
\text { behaviours that help them } \\
\text { deal with the } \\
\text { entrepreneurial day-to-day } \\
\text { challenges }\end{array}$ & $\begin{array}{l}\text { Role model observations } \\
\text { contribute to learning } \\
\text { about small business } \\
\text { management }\end{array}$ & $\begin{array}{l}\text { Observations of } \\
\text { role models } \\
\text { continues post- } \\
\text { start-up in } \\
\text { different social } \\
\text { contexts } \\
\text { Observations } \\
\text { post-start-up are } \\
\text { informed by } \\
\text { entrepreneurial } \\
\text { challenges } \\
\text { Observations } \\
\text { post-start-up are } \\
\text { associated with } \\
\text { particular learning } \\
\text { tasks }\end{array}$ \\
\hline
\end{tabular}




\begin{tabular}{|c|c|c|c|}
\hline & $\begin{array}{l}\text { Other } \\
\text { entrepreneurs } \\
\text { (active } \\
\text { entrepreneurs) }\end{array}$ & $\begin{array}{l}\text { 'They have been going for } 10 \text { years and last year they made millions of } \\
\text { pounds and the guys there, they are great guys. If you look back at their } \\
\text { history, they started off in a garage and they nearly went bankrupt about } 3 \\
\text { times. That was for } 8 \text { years, } 8 \text { years of struggle and keep seeing the promise of } \\
\text { it, keep seeing the opportunity for them' (Bruno) } \\
\text { 'I just think the way he does it isn't really good. He has procedures in place, } \\
\text { it's only a small firm like mine. He does staff appraisal, he does bonus } \\
\text { schemes, staff go on training courses, staff meetings' (Peter) } \\
\text { 'And P was always one of those guys. P, I need this last minute and he could } \\
\text { always get it done, he was a doer' (Carola) } \\
\text { 'He was far more a musical director and he did pick up a lot of work' } \\
\text { (Roderick) } \\
\text { 'I will call her with a problem and she will give me a very task-oriented, } \\
\text { specific kind of solution. She gives me cold heart facts, this is how it is. Here } \\
\text { are your numbers; you can't do that at that cost' (Ray) }\end{array}$ & $\begin{array}{l}\text { Entrepreneurs observe } \\
\text { behaviours that } \\
\text { demonstrate distinct } \\
\text { approaches to exploit } \\
\text { entrepreneurial } \\
\text { opportunities } \\
\text { Entrepreneurs observe high } \\
\text { performance behaviours }\end{array}$ \\
\hline
\end{tabular}

Role model observations contribute to learning about business and smal business management

trepreneurs

I just think the way he does it isn't really good. He has procedures in place,

'And $P$ was always one of those guys. $P$, I need this last minute and he could ne, he was a doer' (Carola)

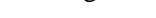


Figure 1 Theoretical Model Pre-Start-Up

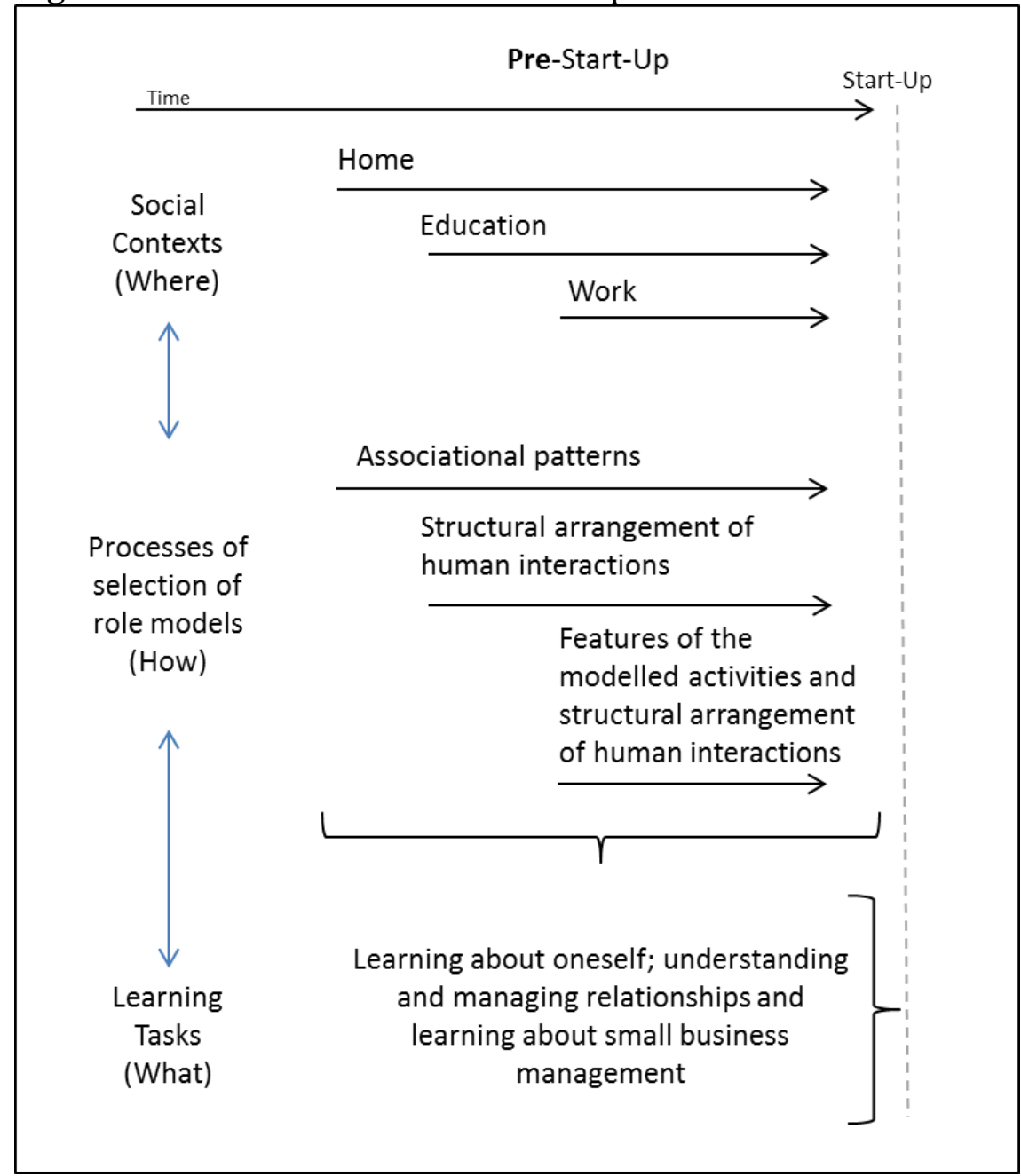


Figure 2 Theoretical Model Post-Start-Up

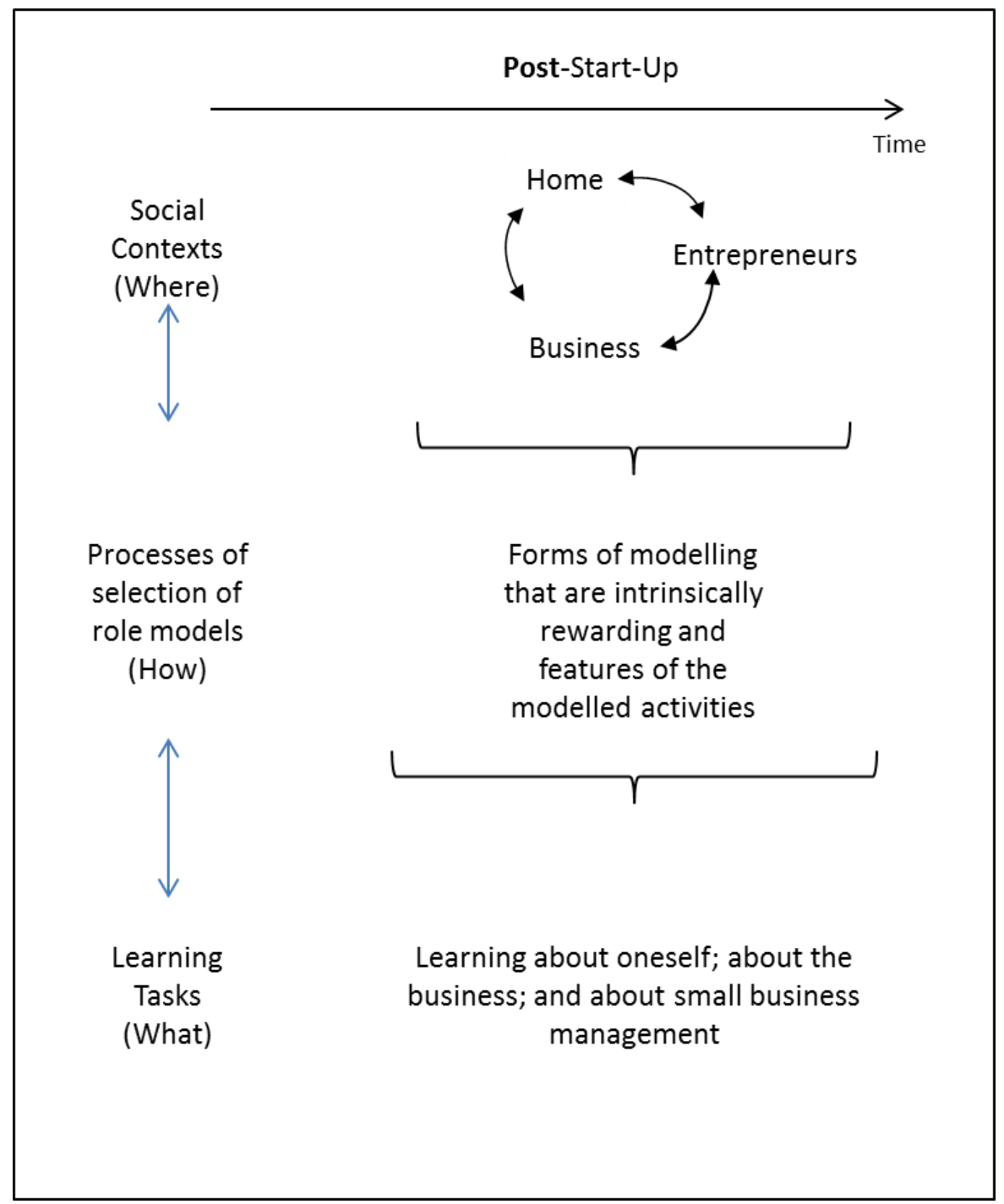

